\title{
DNA TYPING: A NEW INVESTIGATORY TOOL
}

\section{INTRODUCTION}

Experts describe DNA typing ${ }^{1}$ - a test used to identify persons based on the genetic code found in their DNA (deoxyribonucleic acid)as "the most significant break through in resolving serious crime since fingerprinting was invented."2 Because all of a person's cells carry the saine DNA, and each person's DNA is unique (except in the case of identical twins), DNA typing can identify people with "near-perfect accuracy."3

A recent Enghish case, Regina v. Pitchfork, ${ }^{4}$ vividly illustrates DNA typing's tremendous potential as an investigatory tool. In 1983, a teenage girl was raped and murdered near the village of Enderby. The police were unable to find the murderer. Three years later, another girl was raped and murdered near the same village. Authorities took DNA prints from the semen found on her body and discovered they inatched those taken from the first victim, thus indicating that the same person had committed both crimes. The police then arrested a seventeen-year-old and subjected a sample of his blood to DNA typing. The suspect's DNA prints did not match those found on the victims, however, and the police subsequently released him.

The police then asked all men in the area between thirteen and thirty to voluntarily provide blood samples for DNA typing. Approximately fifty-five hundred men, all but two in the area, complied with the request. One local resident, Colin Pitchfork, was eventually arrested and convicted of the crimes, after a friend admitted he had supplied Pitchfork's sample by using false identification.

1. See infra notes 29-52 and accompanying text.

2. Marshall, "Genetic Fingerprints" May Catch Killer, L.A. Times, March 11, 1987, at 11, col. 4. See also Spenccr v. Virginia, Nos. 881268, 881288 (Va. Sept. 22, 1989) (1989 WL 109529, 109530) (first state supreme court to rule on admissibility of DNA identification in criminal case; held DNA print evidence properly admitted to link defendant to murder victim); Andrews v. State, 533 So. 2d 841, 842-43 (Fla. Dist. Ct. App. 1988) (first appellate court to rule on admissibility of DNA identification in criminal cases held DNA print identification evidence properly admitted to tie defendant to remaining body fluids on rape victim).

3. Begley, Leaving Holmes in the Dust, Newsweek, Oct. 26, 1987, at 81.

4. See White \& Greenwood, DNA Fingerprinting and the Law, 51 MoD. L. REv. 145, 149-50 (1988); see also Regina v. Pitchfork, The Times, Jan. 23, 1988, at col. 1 (Leicester Crown Court Jan. 22,1988 ) (new forensic technique of DNA fingerprinting used to "crack" the English case); Begley, supra note 3, at 81 (initial suspect in English case released because DNA pattern did not match evidence from crime); DNA Prints, Time, Jan. 26, 1987, at 66; Marshall, supra note 2, at 11, cols. 4-5 (English police connected the deaths of two victims $21 / 2$ years apart through DNA fingerprinting). 
The Pitchfork case demonstrates the power of DNA typing as an investigatory tool. By using DNA typing in their investigation, English law enforceinent authorities not only exculpated an innocent man, but also apprehended the true murderer when all otlier leads proved useless. In the United States, however, the federal Constitution presuniably would prohibit authorities from testing a whole community like Enderby. Because the Supreme Court has classified the taking of blood sainples for testing as a search and seizure under the fourth amendment, 5 police can take samples only after obtaining a warrant based on a showing of probable cause. ${ }^{6}$ The English police clearly could not have shown probable cause to obtain a warrant for all fifty-five hundred men. Moreover, a United States court probably would decline to find that the fiftyfive hundred men waived their fourth amendment rights" by "voluntarily" submitting to the inass testing. Althougl the Britisli police asserted the testing was voluntary, the social pressure to submit to testing, and the resulting suspicion cast on anyone who refused, nost likely would convince United States courts that the testing was not voluntary. ${ }^{8}$ Without probable cause or voluntary action, United States law enforcennent authorities could not have iniplemented such a progran.

However, United States authorities may be able to use DNA typing as an investigatory tool on a linited scale. Frequently, identification techniques like DNA typing are most helpful when police lack probable cause to arrest. Pohice miglit be able to use DNA typing to both inculpate and exculpate if they could type the forensic sainples of hair, blood, saliva, semen, and skin discovered at the scene of a crime and conipare

5. Schmerber v. California, 384 U.S. 757, 769-70 (1966); see also Note, Analyzing the Reasonableness of Bodily Intrusions, 68 MARQ. L. REv. 130, 133-34 (1984) (courts focus on evidence, defendant's privacy right, society's interest in criminal prosecution, and invasive procedures used to determine reasonableness of intrusion).

6. See Dumbra v. United States, 268 U.S. 435, 441 (1925) ("Probable cause has been defined by this Court as 'reasonable ground of suspicion supported by circumstances sufficiently strong in themselves to warrant a cautious man in the belief that the party is guilty of the offense with which hc is charged.' "); see also W. LAFAve, SEARch and SeIzURE: A TrEatise ON THE Fourth AMENDMENT $\S 3.2$ (1978) (discussing several tests and definitions of probable cause); Note, Detention to Obtain Physical Evidence Without Probable Cause: Proposed Rule 41.1 of the Federal Rules of Criminal Procedure, 72 CoLUM. L. REv. 712, 712 (1972) (police must have probable cause to believe that the suspect committed the crime).

7. The intense peer pressure to comply with the testing could be seen as sufficiently coercive as to negate consent. See Schneckloth v. Bustamonte, 412 U.S. 218, 228 (1973) ("But the Fourth and Fourteenth Amendment requires that a consent not be coerced, by explicit or implicit means, by implied threat or covert force. For, no matter how subtlely the coercion was applied, the resulting 'consent' would be no more than a pretext for the unjustified police intrusion....").

8. See Marshall, supra note 2, at 13, col. 2 (discussing local men's reservations about testing and the "atypical social pressure" of close-knit middle-class villagers to comply). 
them to the DNA prints of suspects. ${ }^{9}$ In cases where a forensic sample is the only evidence that police discover, an arguably strong state interest in DNA typing exists. On the other hand, individuals greatly value the privacy from state intrusion protected by the fourth amendment. ${ }^{10}$ In light of the unprecedented reliability of DNA typing, the law must find new ways to balance law enforcement's interest in crime investigation with individuals' fourth ainendment riglit to privacy. ${ }^{11}$

The Supreme Court suggested a new approach to this dilemma in Davis v. Mississippi. ${ }^{12}$ In this case the Court proposed in dictum that the Constitution may allow a magistrate to autlorize police to detain briefly a suspect for fingerprinting, another highly reliable identification techmique, witlout showing probable cause. ${ }^{13}$ Based on this dictum, the Committee on Rules of Practice and Procedure of the Judicial Conference of the Umited States proposed Federal Rule of Criminal Procedure 41.1.14 The proposed rule authorizes magistrates to order criminal suspects to submit to nontestimonial identification procedures on less than probable cause. ${ }^{15}$ The rule permits the following identification procedures: "identification by fingerprints, palm prints, footprints, measurements, blood specimens, urine specimens, saliva samples, hair sanples, or other reasonable physical or medical examination, liandwriting exemplars, voice samples, pliotograplis, and lineups."16 This group of identification procedures presumably would include taking samples for DNA typing. Although the Judicial Conference did not ultimately approve the

9. See White \& Greenwood, supra note 4, at 149 (DNA typing's potential to establish innocence is no less important than its potential to incriminate).

10. See Schmerber v. California, 384 U.S. 757, $769-70$ (1966) ("The interests in human dignity and privacy which the Fourth Amendment protects forbid any such [blood testing] intrusions on the mere chance that desired evidence might be obtained.").

11. See Note, The Constitutionality of Compulsory Identification Procedures on Less than Prob. able Cause: Reassessing the Davis Dictum, 89 Dick. L. REv. 501, 501-02 (1985) ("To resolve the conflict between the police need and the individual's rights, a court must determine at what point a suspect is sufficiently connected to the commission of a crime that the public interest in solving that crime justifies subjecting him to the procedure against his will.").

12. 394 U.S. 721 (1969).

13. Id. at 727.

14. Committee on Rules of Practice and Procedure, Judicial Conference of the United States, Preliminary Draft of Proposed Amendments to the Fed. Rules of Criminal Procedure for the United States Dist. Court and the Fed. Rules of Appellate Procedure, 52 F.R.D. 409, 462 (1971).

15. A federal law enforcement officer or attorney for the government must appear before a federal magistrate and swear to an affidavit that establishes: (1) that there is probable cause to believe an offense has been committed; (2) that there are reasonable grounds, not amounting to probable cause to arrest, to suspect that the person described in the affidavit committed the offense; and (3) that the results of specific nontestimonial identification procedures will be of material aid in determining whether the person named in the affidavit committed the offense. Id. at 463 .

16. Id. at $466-67$. 
proposed rule, ${ }^{17}$ nine states enacted similar legislation or court rules of their own ${ }^{18}$-1nost of which would probably allow DNA typing on less than traditional probable cause.

This Note argues that, by adopting such legislation, Congress and state legislatures could allow law enforceinent authorities to effectively use DNA typing as an investigatory tool and still preserve individual rights. First, the Note describes the DNA typing process itself ${ }^{19}$ and its advantages and disadvantages relative to other identification techniques. ${ }^{20}$ Second, the Note discusses the traditional constitutional limitations on identification techniques, how Davis v. Mississippi and subsequent decisions may have changed these limitations, and how DNA typing fit with these limitations. ${ }^{21}$ Third, the Note discusses the balancing approach of Proposed Rule 41.1 and similar balancing schemes used by some states. ${ }^{22}$ Fourth, the Note argues that DNA typing is particularly well-suited to the balancing approach suggested by Proposed Rule 41.1.23 Finally, the Note proposes that the states and the federal government adopt rules like Proposed Rule 41.1, which authorize DNA typing on less than probable cause and under the supervision of a neutral magistrate. ${ }^{24}$

\section{The Process of DNA Typing}

\section{A. Background.}

Genes carry the genetic information found in the cells of individuals and this genetic information creates an individual's "basic blueprint," determining everything from sex to eye color. ${ }^{25}$ DNA (deoxyribonucleic acid) is the material of which genes are composed. DNA is present in the

17. United States v. Holland, 552 F.2d 667, 673-74 (5th Cir. 1977) (holding that district court had no jurisdiction to order inmate to give handwriting exemplar; discussed failure of the proposed rule in that context), mandate aff'd, opinion withdrawn, 565 F.2d 383 (5th Cir. 1978).

18. Alaska R. CT. 16(c)(1)-(2) (1988); ARIZ. Rev. Stat. ANN. § 13-3905 (1978); Colo. R. CRIM. P. 41.1 (1984); IDAHo CODE § 19-625 (1987); IOWA CODE ANN. \$ 810.1-.2 (West 1978 \& Supp. 1988); Neb. Rev. STAT. $\S \S 29-3301$ to -3307 (1985); N.C. GEN. STAT. $\S \S 15 A-271$ to -282 (1983); UTAH CODE ANN. § 77-8-1 to -4 (1982); VT. R. CRIM. P. 41.1 (1983).

19. See infra notes $25-52$ and accompanying text.

20. See infra notes 53-79 and accompanying text.

21. See infra notes 80-104 and accompanying text.

22. See infra notes $105-29$ and accompanying text.

23. See infra notes $130-34$ and accompanying text.

24. See infra notes $135-42$ and accompanying text.

25. See Marshall, supra note 2, at 13, col. 1 ("DNA ... [is] found in the chromosomes of all living beings. Chromosomes contain an individual's basic blueprint, determining everything from sex to eye color"); White \& Greenwood, supra note 4, at $145-46$ ("Since there are probably between ten thousand and one hundred thousand genes in humans and about one-third are variable, the number of possible combinations is inconceivably large. That is why each of us, apart from identical twins, is genetically unique."). 
genes of virtually every cell of the body in the form of long chains of nucleotide bases ${ }^{26}$ twisted into a double-helix structure (resembling a twisted ladder). The nucleotide bases (A, T, C, and $\mathrm{G}$ ) bind together in specific sequences that create the language of the genetic code. ${ }^{27}$ Each cell reads only the part of the code necessary to do its job, but every cell contains the entire code. Thus, DNA typing theoretically can be performed on a sample taken from any cell of the body. ${ }^{28}$

During the early 1980s, Dr. A. J. Jeffreys of the University of Leicester developed DNA typing in Great Britain. ${ }^{29}$ The process cuts DNA into fragments and allows scientists to compare the fragments according to number and size by arranging them into a bar code pattern..$^{30}$ Because of the unique nature of every individual's DNA, no two individuals should produce identical DNA patterns. ${ }^{31}$

The first step in the DNA typing process is to extract DNA from a biological sample. ${ }^{32}$ A sample inay consist of blood, semen, skin, saliva, or hair roots. ${ }^{33}$ Once the DNA is isolated, it is treated with protein molecules called restriction enzymes that cut it into pieces. ${ }^{34}$ The enzymes cut DNA only at very specific points (at specific base sequences) and will cut the same person's DNA in the same places every time they are applied. $^{35}$ This process thus creates DNA fragments of a characteristic

26. See, e.g., Kelly, Rankin \& Wink, Method and Application of DNA Fingerprinting: A Guide for the Non-Scientist, 1987 CRIM. L. REV. 105, 106 (1987) (nucleotide bases are four building blocks that compose DNA and order in which they occur provides information required to assemble and regulate construction of the body).

27. Id.; Burk, DNA Fingerprinting: Possibilities and Pitfalls of a New Technigue, 28 JURIMETRICS J. 455, 457 (1988).

28. See supra note 27 and accompanying text.

29. White \& Greenwood, supra note 4 , at 145.

30. Id. at $146-47$.

31. Id. at 147 ("Because there are so many minisatellites [nucleotide base sequences] and because not every one is present in every individual, the chances of the 'bar code,' that is the minisatellite profile, of two unrelated individuals being identical is less than one in five thousand million million.").

32. It may be difficult to extract DNA from a biological sample if moisture or bactcria have degraded the DNA or if the sample is too small. See Moss, DNA-The New Fingerprints, 74 A.B.A. J., May 1, 1988, at 66-67 ("About 50 percent of the rape cases referred to Lifecodes get no results either because of a small sample size, or because the vaginal swab turned up no semen at all.") However, scientists claim that if a DNA sample has been altered in any way, it will not produce a false positive-it will simply fail to form a DNA pattern. See LIFECODES CoRP., DNA-PRINT IDENTIFICATION TEST 6 (1986).

33. See Burk, supra note 27 , at 469 ("In theory, DNA analyzed from any body tissue should yield a pattern identical to the pattern from any other body tissue."); Moss, supra note 32, at 66 .

34. Burk, supra note 27, at 457.

35. Different restriction enzymes "recognize" different base sequences which are scattered at random in the gene; each enzyme will cut the DNA only at the sequence it recognizes. Therefore, a specific enzyme will cut a person's DNA into the same pieces every time. Burk, supra note 27, at 457-58. 
number and size for each individual tested.

The fragments are then placed in an agorose gel (which resembles a slab of gelatin) so that their number and length may be examined. An electric current is run through the gel in a process called gel electrophoresis. ${ }^{36}$ Because the fragments have a negative charge, the current causes them to move through the gel toward the positive electrode. ${ }^{37}$ The fragments move at differing speeds according to their length. The larger fragments move more slowly and stay near the top of the gel; the smaller fragments move more quickly and end up toward the bottom of the gel. ${ }^{38}$ The fragments thus arrange themselves throughout the gel according to size.

Because the gel is difficult to work with, the fragment pattern is then transferred to a nitrocellulose filter (which looks like a heavy piece of paper) through a process called "Southern Blotting." 39 Once fixed to the filter, a radioactive "gene probe" is applied to the pattern. The probe binds only to specific base sequences and thereby "marks" them. ${ }^{40}$ To expose the "marks," an X-ray film is placed on the filter for several days. ${ }^{41}$ The film eventually develops into a picture displaying the marked sequences as dark bands. ${ }^{42}$ This pattern of bands, which resembles a supermarket bar code, is a DNA identification print. This print will be compared to other DNA prints in much the same way fingerprints are compared for identification. ${ }^{43}$ Whereas fingerprints are compared by examining the distinctive pattern forined by the tiny ridges on the skin of a subject's hand, DNA prints are compared by examining the distinctive pattern forned by a subject's marked gene fragments. ${ }^{44}$

\section{Id. at 459 .}

37. Id.

38. The movement of the fragments through a gel is similar to the movement of a person carrying a rod through a dense forest. If the rod is a short baton, she may move rapidly. If the rod is a long pole, however, her movement will be impeded and she will move quite slowly. By the same principle, short DNA fragments move a greater distance through the gel matrix; large fragments move more slowly.

Id. at $459-60$.

39. Id. at 460 (Southern Blotting transfers fragments in exactly the same positions they occupied in gel).

40. The gene probe seeks out a DNA fragment that carries all or part of its complementary base sequence and binds to that fragment. The radioactive marker on the probe causes the bound fragments to light up, allowing their positions to be identified. LIFECODES CORP., supra note 32, at 26-27; Burk, supra note 27, at 460 .

41. Burk, supra note 27 , at 460 .

42. Id.

43. Id. at 463; Kelly, Rankin \& Wink, supra note 26, at 108; White \& Greenwood, supra note 4, at 147; see also LIFECODES CORP., supra note 32, at 26-27 (semen and blood specimens from same person will result in same two patterns).

44. See A. MOENSSENS, FINGERPRINTS AND the LAW 10-24 (1969); W. SCOTT, FingerPRINT MECHANICS: A HANDBOOK, 5-11 (1951) (discussing characteristics or "trademarks" by which fin- 
According to officials at Cellmark Diagnostics, the company which holds an exclusive North American license to market Jeffreys' technique, there is only a one in 30 bilhon chance that any two persons' DNA prints will match and create a false positive result (except in the case of identical twins). ${ }^{45}$ The two other labs in the United States that offer DNA typing-Lifecodes Corporation (in Tarrytown, New York) and Cetus Corporation (in Emeryville, California) -claim slightly different rates of rehiability. Lifecodes, which uses a technique very similar to Cellmark, claims a 99.9 percent probability that biological specimens are derived froin the same person if their two DNA patterns match. ${ }^{46}$ Unlike the other two coinpanies, Cetus does not guarantee that its typing will identify a suspect with virtual certainty; ${ }^{47}$ it claims only that "one out of every several thousand people . . . could have left a particular sample."48 Cetus's techniques, however, can type smaller biological samples than the other two companies because it uses a technique that "amplifies" the target DNA by creating numerous copies of it. Theoretically, Cetus can test a sample as small as a single hair cell, ${ }^{49}$ and the company has actually produced a print from a sample as small as 40 sperm heads. ${ }^{50}$ The other labs, Cellmark and Lifecodes, require larger samples, such as several hundred thousand sperm heads or a well-soaked blood stain the size of a quarter. ${ }^{51}$ Unfortunately, police are less likely to find samples of this size at the typical crime scene. Indeed, many Cellmark and Lifecodes tests have produced inconclusive results because the samples were too small for their methods to work effectively. ${ }^{52}$

\section{B. Advantages of DNA Typing.}

The primary advantage of DNA typing is its remarkable accuracy and thus its ability to provide nearly positive identification. This is especially true of the Cellmark and Lifecodes techniques. Advocates of DNA typing for criminal investigation claim that it can identify suspects

gerprints are identified); infra notes 57-58, 80 and accompanying text; $c f$. LIFECODES CORP., supra note 32, at 26-28 (outlining procedure for DNA-PRINT Identification Testing).

45. Marshall, supra note 2, at 13, col. 1; Thompson, DNA Fingerprinting: Who Does It and How, 8 Cal1F. Law., June 1988, at 41.

46. LIFECODES CORP., supra note 32 , at 1.

47. Thompson, supra note 11, at 41 .

48. Id.

49. Id.

50. Id.

51. Id.; see also Moss, supra note 32, at 66 (spot of dried semen size of nickle is large enough sample).

52. See Thompson, supra note 45 , at 41 (inconclusive results due to low molecular weight of sample). 
with "virtual certainty."53 DNA typing works much like fingerprinting and is much more accurate than traditional blood, semen, or hair-typing tests. ${ }^{54}$

DNA typing is also unique because of the range of forensic samples that it can test. ${ }^{55}$ Potential samples include blood, semen, hair, and skin scrapings. ${ }^{56}$ Police are often more likely to find these kinds of samples at crime scenes than fingerprints, ${ }^{57}$ particularly in rape investigations where semen samples may be the only available evidence. ${ }^{58}$

DNA typing can also be performed on forensic samples that have dried and aged, whereas traditional lab tests cannot. ${ }^{59}$ The DNA's structure is sufficiently hardy so that law enforcement authorities are able to reopen old cases and compare forensic samples from a number of crimes, even if the samples have aged substantially, to see whether the same assailant was involved. Successful tests have been performed on samples up to four years old.60

In addition, law enforcement authorities could easily computerize the data from DNA prints because of their bar code structure. ${ }^{61}$ Fingerprints have sometimes been computerized, but their structure is too complex to accurately symbolize and efficiently search by computer. ${ }^{62}$ In contrast, DNA primts are easy to symbolize in a numeric form that is suitable for computer access. ${ }^{63}$

53. See Moss, supra note 32 , at 66 .

54. Cf. id. at 66-67 (The traditional HLA (human leukocyte antigen) blood test has an exclusion rating of only 90 to 95 percent (meaning that there is a 90 or 95 percent certainty that any two matching specimens came from the same person) and, for some common blood types, the exclusion rating is as low as 50 percent. Traditional hair testing only determines whether hair found at a crime scene has characteristics such as color and size consistent with those of a suspect.). But see supra note 16 and accompanying text (Cellmark claims only one in 30 billion matching samples would not come from same person).

55. LIFECODES CORP., supra note 32 , at 7.

56. Moss, supra note 54 , at 66 .

57. Lifecodes CoRP., supra note 32, at 7-8. Fingerprints are often not available at all to aid police investigations.

In the majority of rapes and in a high percentage of other crimes, investigators are unable to recover fingerprints, either because the prints are not present or because they have been left on surfaces that preclude fingerprint analysis. By contrast, it is possible to obtain results with the DNA-PRINT Identification Test in nearly all cases in which there is suffId.

cient biological evidence from the assailant.

58. See id. at 8 .

59. Moss, supra note 32 , at 66 .

60. Burk, supra note 27, at 464 ("Success has been reported in fingerprinting DNA from dried blood and semen samples up to four years old.").

61. See LifECODES CORP., supra note 32 , at 8.

62. Id.; see also Thompson, supra note 45 , at 42 .

63. California Attorney General John Van de Kamp predicts that within three to five years his office will have a database of genetic fingerprints on computer. When the system is on-line, local law 
DNA typing can be particularly effective in rape cases. First, it can be used to test each semen sample of sufficient size. ${ }^{64}$ Testing techniques traditionally used in rape investigations identify suspects based on antigens-proteins that are normally present in semen. ${ }^{65}$ Nearly twenty percent of all males, however, do not secrete antigens and thus traditional testing methods cannot identify those males. DNA typing does not have this limitation, however, because semen will leave DNA prints.

Another advantage in rape cases is that the DNA found in sperm can be separated from the vaginal cells often mixed with sperm in forensic samples. ${ }^{66}$ Although this mixing has often thwarted attempts at traditional testing of semen, it will not hinder DNA typing. ${ }^{67}$

\section{Disadvantages of DNA Typing.}

The major disadvantage of DNA typing is that it is "very labourintensive and needs both meticulous expertise and much experience in the reading and interpretation of the bands." 68 The test is also very time intensive, often requiring several days to complete. ${ }^{69}$

As of June 1988, only three private labs in the United States offered the process for crimmal investigations. ${ }^{70}$ Some experts are concerned that these labs have not tested their experimental techniques sufficiently to support their statistical claims. ${ }^{71}$ Others are concerned that the profit motive of these private labs may interfere with the integrity of their test-

enforcement officials say that "most rapists might as well leave calling cards at the scenc of thcir crime." Thompson, supra note 45 , at 42 . Van de Kamp also has expressed concern that such a database may threaten privacy interests. "It is one thing to have fingerprints and criminal histories accessible to tens of thousands of peace officers. . . . It is another to have information on-line that can mark you as a carrier of AIDS, or prove that you are not genetically related to either of your parents." Moss, supra note 32, at 70. Experts claim, however, that the bar codes contained in such a database would reveal very little except a suspect's identity. See infra notes 75-77 and accompanying text.

64. Moss, supra note 32 , at 66 .

65. Id.

66. See Gill, Jeffreys \& Werrett, Forensic Application of DNA 'Fingerprints,' 318 NATURE 577 (1985) ("sperm nuclei can be separated from vaginal cellular debris, obtained from semen-contaminated vaginal swabs, enabling positive identification of the male donor/suspect").

67. Burk, supra note 27, at 464.

68. White \& Greenwood, supra note 4, at 147 (quoting Dodd, DNA Fingerprinting in Matters of Family and Crime, 26 MED. SCI. \& LAW 5 (1986)).

69. Id.

70. Thompson, supra note 45 , at 41 (Cellmark Diagnostics in Germantown, Maryland; Lifecodes Corp. in Tarrytown, New York; and Cetus Corp. in Emeryville, California).

71. Thompson, DNA's Troubled Debut, 8 CAL1F. LAw. 36, June 1988, at 36, 44 (statement by Fredrick Millar, supervising deputy attorney general in San Diego, noting that "private firms for the most part have not put their technology to the test of independent validation studies"). 
ing. ${ }^{72}$ Increased competition, investigation, and government involvement should reduce these concerns. For example, at least one other company, E. I. Du Pont de Nemours \& Co., is currently seeking to develop an alternative technique, ${ }^{73}$ and the FBI is examining the methods used by Cellmark, Lifecodes, and Cetus to determine the best method to use in its own lab. ${ }^{74}$

Some commentators have noted that as the public becomes aware of the effectiveness of DNA typing, people will be concerned that authorities will use this technique ${ }^{75}$ to discover private imformation concerning family relationships, susceptibility to disease or mental illness, or level of intelligence, and not merely the identity of criminals. Advocates of DNA typing, however, claim that these concerns are largely unfounded the bar code form of DNA prints reveals virtually no genetic information contained in a person's DNA. ${ }^{76}$ One commentator even stated that "genetic privacy" concerns "would seem to be unwarranted, and probably deserve minimal court attention." 77 A highly trained scientist inight glean from the patterns some information concerming genetic disease, but this is true of many cominonly considered biochemical tests. ${ }^{78}$

Finally, the accuracy of DNA typing, hike any other forensic test, is limited by the skills of persons administering the test. Human actors exercise their judgment in performing and evaluating DNA tests, and they always remam capable of laboratory error. ${ }^{79}$ Furthermore, DNA typing cannot prove that a suspect committed a crime no matter how accurately it can identify his forensic sample. The presence of a suspect's forensic sample at the scene of a crime is always open to an innocent explanation. These criticisms, discounting the predictability of the test,

72. See Thompson, supra note 71, at 44 ("[of] the handful [of DNA researchers] working in forensics, almost none are law enforcement personnel. They are all attached to private laboratories, which by the way, have a proprietary interest in their own procedures.") (statement of California Attorney General John van De Kamp); Burk, supra note 27, at 468 n.60.

73. See, e.g., Thompson, supra note 47 , at 43 (company currently developing "laser sequencing" technique).

74. Moss, supra note 32 , at 70 .

75. See, e.g., Burk, supra note 27 , at 471 ("In a society concerned with blood tests exposing the stigma of AIDS, some might fear the ultimate invasion of privacy: examination and exposure of a person's genetic makeup.").

76. Id. ("patterns created by DNA fingerprinting show nothing concerning a person's intelligence, sex, or outward physical appearance"); see also Marshall, supra note 2, at 13, col. 1 (Dr. Jeffreys claims DNA fingerprints contain no information regarding sex or even species of donor).

77. Burk, supra note 27 , at 471 .

78. See id.; cf. infra note 35 and accompanying text.

79. See Burk, supra note 27, at 465 ("a degree of human judgment enters the test when the autoradiographs [bar codes] are interpreted .... The person who determines whether or not a certain band should be disregarded should have considerable experience in reading autoradiographs."). 
however, also apply to other commonly used forensic tests and are not criticisms specific to DNA typing.

\section{Constitutional Limitations on DNA Typing}

DNA typing is analogous to two other nontestimonial identification techniques: fingerprinting and blood typing. The process is as accurate and potentially incriminating as fingerprinting, ${ }^{80}$ and requires no more intrusion into a suspect's body than blood typing. ${ }^{81}$ Police must have a warrant based on probable cause to take either fingerprints or blood samples when gathering evidence. ${ }^{82}$ The Supreme Court has held that both techniques require probable cause because they fall under the fourth amendment's prohibition of unreasonable searches and seizures. ${ }^{83}$

Historically, the Supreme Court has held that searches and seizures not based on probable cause are unconstitutional. ${ }^{84}$ Within the last twenty-five years, however, the Court has relaxed this strict interpretation of the fourth amendment. The two most important cases that indicate a more flexible interpretation are Camara v. Municipal Court ${ }^{85}$ and

80. See Moss, supra note 32, at 66 ("[c]ommercial laboratories marketing the tests say their research shows that DNA typing is as accurate as a fingerprint"); supra notes 45-52 and accompanying text; see also Davis v. Mississippi, 394 U.S. 721, 727 (1969) ("fingerprinting is an inherently more reliable and effective crime-solving tool than eyewitness identifications or confessions"); A. MoENSSENS, FINGERPRINTS AND THE LAW 28 (1969) ("Because of the fact that fingerprint technicians require at least eight matching characteristics in both prints and no unexplained points of difference, it may be said safely that even though an art is involved, different experts would nevertheless come to the same conclusion of identity with respect to a given latent and inked print. ... The certainty inherent in this process of comparison accounts for the fact that, in the area of fingerprint evidence, there is seldom a battle of opposing experts.").

81. See Burk, supra note 27, at 470 ("Samples for DNA fingerprinting may also be obtained from sources such as hair roots or skin scrapings; these might be viewed as even less intrusive than blood sampling."); see also Schmerber v. California, 384 U.S. 757, 771 (1966) ("[S]uch tests [i.e., blood tests] are a commonplace in these days of periodic physical examinations and experience with them teaches that the quantity of blood extracted is minimal, and that for most people the procedure involves virtually no risk, trauma, or pain.").

82. See supra notes 5-6 and accompanying text.

83. See Davis v. Mississippi, 394 U.S. at 727 (fingerprinting); Schmerber v. California, 384 U.S. at 770 (blood samples).

84. See Henry v. United States, 361 U.S. 98, 100, 102 (1959) ("The requirement of probable cause has roots that are deep in our history. ... It is important, we think, that this requirement be strictly enforced, for the standard set by the Constitution protects both the officcr and the citizen. If the officer acts with probable cause, he is protected even though it turns out that the citizen is innoccnt. ... And while a search without a warrant is, within limits, permissible if incident to a lawful arrest, if an arrest without a warrant is to support an incidental search, it must be made with probable cause."); supra note 6 and accompanying text; see also, United States v. Harris, 403 U.S. 573, 577 (1971) (Court examined the showing of probable cause in order to evaluate compliance with the fourth amendment); Wong Sun v. United States, 371 U.S. 471, 478 (1963) (opinion focused on whether arrests met the probable cause standard prescribed by the fourth amendment, finding that reliance on unfamiliar informants and uncorroborated admissions of the accused were insufficient).

85. 387 U.S. 523 (1967). 
Terry v. Ohio. ${ }^{86}$ The Camara case addressed the question of whether the inspection of dwellings for health and fire prevention purposes was an "unreasonable" search and seizure under the fourth amendment such that law enforcement officials would need warrants based on probable cause. To answer this question, the Court formulated a "balancing test" for search and seizure. ${ }^{87}$ In formulating this test, the Court narrowed the range of searches and seizures considered "unreasonable" under the fourth amendment, while acknowledging that there is "no ready test for determining reasonableness other than by balancing the need to search against the invasion which the search entails." 88 To properly balance these interests, the Court declared that it was necessary "first to focus upon the governmental interest which allegedly justifies official intrnsion upon the constitutionally protected interests of the private citizen."89 The Court then concluded that to require probable cause to inake health and fire inspections frnstrates admimstration of these inspections, ${ }^{90}$ and that the inspections themselves are reasonable searches of private property. The Court rested its conclusion on the history of both judicial and public acceptance of area inspections, the lack of administratively feasible alternatives, and the limited degree to which such inspections imvade a citizen's privacy. ${ }^{91}$

The Court also applied the balancing test in Terry v. Ohio. ${ }^{92}$ It balanced governmental interests against individual interests to determme if a police force's "stop and frisk" procedure, in which officers searched suspects without warrants, was "reasonable" under the fourth amendment. ${ }^{93}$ The Court concluded that society's mterest in preventing crime and protecting police officers outweighs an individual's interest in avoiding the minor interferences with personal liberty that a "stop and frisk" procedure imposed. 94 The Court based its conclusion on the importance of the government's interest in investigating crime, ${ }^{95}$ law enforcement officers' need to protect themselves, ${ }^{96}$ and the limited extent to which the "stop and frisk" procedure invaded a citizen's privacy. ${ }^{97}$

86. 392 U.S. 1 (1968).

87. Camara, 387 U.S. at 536-37; Comment, Detention for Taking Physical Evidence Without Probable Cause, 14 ARIz. L. REv. 132, 138 (1972).

88. Camara, 387 U.S. at 536-37; see also Comment, supra note 87, at 138.

89. Id. at $534-35$.

90. Id.

91. Id. at 537.

92. 392 U.S. 1, 21 (1968).

93. See id. at 20-21; Comment, supra note 87 , at 138.

94. Id. at 22, 27, 29-30; see also Comment, supra note 87, at 138-39.

95. Terry, 392 U.S. at 23.

96. Id. at 24 .

97. Id. at 24-25. 
In another case, Davis v. Mississippi, 98 the Court applied the balancing test to pre-arrest identification procedures with the opposite result. The Court concluded that government interests did not justify the prolonged detention of several rape suspects for fingerprinting and questioning for less than probable cause. Nevertheless, it also recognized in dicta that there may be times when, "because of the unique nature of the fingerprinting process, ... detentions [for fingerprinting] might, under narrowly defined circumstances, be found to comply with the Fourth Amendment even though there is no probable cause in the traditional sense." 99 Because DNA typing exhibits the same "unique nature" that made the Court look favorably upon fingerprinting, the fourth amendment balancing test arguably could permit DNA typing on less than probable cause.

In Davis, the Court detailed the unique nature of fingerprinting and its implications on a person's privacy:

Detention for fingerprinting may constitute a much less serious intrusion upon personal security than other types of police searches and detentions. Fingerprinting involves none of the probing into an individual's private life and thoughts that marks an interrogation or search. Nor can fingerprint detention be employed repeatedly to harass any individual, since the police need only one set of each person's prints. Furthermore, fingerprinting is an inherently more reliable and effective crime solving tool than eyewitness identifications or confessions and is not subject to such abuses as improper line-up and "third degree." Finally, because there is no danger of destruction of fingerprints, the limited detention need not come unexpectedly or at an inconvenient tinie. ${ }^{100}$

Because DNA typing has each of the qualities that the Davis court attributed to fingerprimting, ${ }^{101}$ the Davis dicta suggests that the fourth amendment would allow DNA typing on less than probable cause "under narrowly defined circumstances." However, one important difference between DNA typing and fingerprinting remains. DNA typing requires a sample of blood, saliva, skin, semen, or hair, and fingerprinting does not. Obtaining these samples may involve a greater intrusion in a person's privacy than taking ink prints of the surface of suspects' fingers. In this regard, DNA typing would more closely resemble blood typing than fingerprinting.

In 1966, the Supreme Court decided Schmerber v. California, the

98. 394 U.S. 721 (1969).

99. Id. at 727. The Court failed to elaborate on what "narrowly defined circumstances" may be. See id. at 727 .

100. Id.

101. See infra notes $130-34$ and accompanying text. 
leading case on taking blood samples for evidence. ${ }^{102}$ In evaluating a California procedure whereby police tested blood-alcohol levels without probable cause, the Schmerber Court ruled that law enforcement officials need search warrants to intrude into a person's body for evidence. The Court, however, did himt at the balancing test that it would articulate several years later in Camera and Terry. Stating that the "Fourth Amendment's proper function is to constrain, not against all intrusions as such, but against intrusions which are not justified in the circumstances, or which are made in an improper manner," 103 the Court found nothing inherently unreasonable about physicians taking blood samples for law enforcement personnel "in a hospital environment according to acceptable inedical practices." 104 The Court emphasized that "for most people the procedure involves virtually no risk, trauma or pain." 105

Indeed, DNA typing can easily accommodate those suspects for whom blood testing involves substantial risk, trauma, or pain. Because of DNA typing's flexibility, suspects may provide hair, skin, or saliva samples for typing as alternatives to blood sainples. These alternative samples require no intrusions into a suspect's body nor even require medical supervision.

\section{Balancing Approach of Proposed Rule 41.1 and Other STATE Rules}

In response to the dictum in Davis, the Committee on Rules of Practice and Procedure of the Judicial Conference proposed a new Federal Rule of Criminal Procedure: Rule 41.1 on Nontestimonial Identification. ${ }^{106}$ The Rule authorizes federal magistrates, upon the request of a federal law enforceinent officer or government attorney, to issue orders that require an individual suspected of committing an offense ${ }^{107}$ punishable by more than one year in prison, to submit to certain identification procedures. ${ }^{108}$ The procedures include: "identification by fingerprints, palm prints, footprints, measurements, blood specimens, urine speci-

102. 384 U.S. 757 (1966).

103. Id. at 768 .

104. Id. at 771 .

105. Id.

106. Committee on Rules of Practice and Procedure, supra note 14, at 462; see also MODEL Code of Pre-Arraignment P. Art. 170 (1975) (Proposed Official Draft) (adopted by the American Law Institute May 20, 1975); UNIF. R. CRIM. P. 436 (1974) (proposed by National Conference of Commissioners on Uniform Law); Standards Relating to Discovery and Procedure Before Trial 34 (1970) (proposed by American Bar Association); S. 2997, 91st Cong., 1st Sess., 115 CONG. REC. 28,896-900 (1969) (proposed Senate bill).

107. Committee on Rules of Practice and Procedure, supra note 14, at 463.

108. Id. at 466 . 
mens, saliva samples, hair samples, or other reasonable physical or medical examination, handwriting exemplars, voice samples, photographs, and lineups." 109 To obtain such an order, a federal law enforcement officer or a government attorney must appear before a federal magistrate and swear to an affidavit that establishes: (1) there is probable cause to believe that an offense lias been committed; (2) there are reasonable grounds, though not amounting to probable cause to arrest, to suspect that the person named or described in the affidavit committed the offense; and (3) the results of specific nontestimonial identification procedures will be of material aid im determining whether the person named in the affidavit committed the offense. ${ }^{110}$ Following the lead of the Davis dictum, this procedure attempts to balance the government's interest in effective investigatory techniques with the individual's right to protection from unreasonable searches and seizures. A federal magistrate must impartially examine all evidence in a given case and can allow police to use the specified nontestimonial identification techniques only if the use of such techriques comports with a balance of interests.

In addition, the proposed Rule prescribes the contents of the magistrate's orders to ensure that individual suspects receive the benefit of full disclosure of the scope and techmiques of the procedure. According to the Rule, an order must state:

(1) that the presence of the person named in the affidavit is required for the purpose of permitting nontestimonial identification procedures in order to aid in the investigation of the offense specified therein; (2) the time and place of the required appearance; (3) the nontestimonial identification procedures to be conducted, the methods to be used, and the approximate length of time such procedures will require; (4) the grounds to suspect that the person named in the affidavit committed the offense specified therein; (5) that the person will be under no legal obligation to subınit to any interrogation or to make any statement during the period of his appearance except for that required for voice identification; (6) that the person may request the federal magistrate to make a reasonable modification of the order with respect to time and place of appearance, including a request to have any nontestimonial identification procedure other than a lineup conducted at his place of residence; and (7) that the person, if he fails to appear, may be held in contempt of court. ${ }^{111}$

The proposed Rule also protects individuals by requiring authorities to conduct all blood tests under medical supervision. ${ }^{112}$ Furthermore, unless authorities arrest someone, the Rule prohibits them from detain-

109. Id. at 466-67.

110. Id. at 463 .

111. Id. at 464-65.

112. Id. at 465 . 
ing that person under a magistrate's order for longer than is reasonably necessary to conduct the test. ${ }^{113}$ Finally, if, after the authorities conclude identification procedures, they still lack probable cause to believe that a suspect committed an offense, the Rule entitles the suspect to bring a motion requesting the inagistrate to issue an order that directs the authorities to destroy all products and copies of the products obtained from the identification procedures. ${ }^{114}$

The American Law Institute, the National Conference of Commissioners on Uniform Law, and the American Bar Association also have proposed schemes resembling Rule 41.1, ${ }^{115}$ and, in 1969, the Senate considered a bill containing provisions similar to Rule 41.1.116 The Senate bill did not survive committee, however, and the Judicial Conference never adopted Proposed Rule 41.1.117 The Conference rejected the Rule partly because "[t]he committees and the Conference should have the benefit of more experience with such procedure in the states and in the District of Columbia and of judicial consideration of the constitutional question involved." 118

Since that time, nine states have enacted statutes or court rules that contain provisions similar to those in Rule 41.1: Alaska, Arizona, Colorado, Idaho, Iowa, Nebraska, North Carolina, Utah, and Vermont. ${ }^{119}$ Only three of these schemes have faced direct constitutional challenge; two courts upheld the constitutionality of the schemes and the other court interpreted the statute to require probable cause.

In one of these constitutional challenges, People v. Madson, ${ }^{120}$ the Colorado Supreme Court upheld Colorado's court rule authorizing nontestimonial identification procedures on less than probable cause. The Colorado Rule allows magistrates to issue nontestimonial identification orders if the police provide evidence by affidavits that establish: (1) probable cause to beheve a crime has been committed; and (2) reasonable grounds, not amounting to probable cause to arrest, to suspect that the

113. $I d$.

114. Id. at 466.

115. See supra note 105.

116. S. 2997, 91st Cong., 1st Sess., 115 CoNG. Rec. 28,896-900 (1969).

117. United States v. Holland, 552 F.2d 667, 673-74 (5th Cir. 1977) ("bill was referred to the Committee on the Judiciary and was never heard of again, apparently dying in Committee"), mandate aff'd, opinion withdrawn, 565 F.2d 383 (5th Cir. 1978).

118. Id. at 674.

119. Alaska R. Cr. 16(c)(1)-(2) (1988); Ariz. Rev. Stat. AnN. 13-3905 (1978); Colo. R. CRIM. P. 41.1 (1984); IDAHo Code ANN. 19-625 (1987); IoWA CODE ANN. 810.1-2 (West 1978 \& Supp. 1988); Neb. Rev. STAT. 29-3301 to -3307 (1985); N.C. GeN. STAT. §§ 15A-271 to -282 (1983); Utah Code ANN. 77-8.1 to 4 (1982); VT. R. CRim. P. 41.1 (1983).

120. 638 P.2d 18 (Colo. 1981). 
person described in the affidavit committed the offense. ${ }^{121}$ In the opinion, the court also noted that the Rule complies with conditions that the Supreme Court established in cases like Terry:

These cases suggest that limited intrusions into privacy on less than probable cause are reconcilable with Fourth Amendinent guarantees when the following conditions exist. First, there must be an articulable and specific basis in fact for suspecting criminal activity at the outset. Second, the intrusion must be limited in scope, purpose and duration. Third, the intrusion must be justified by substantial law enforceinent interests. Last, there must be an opportunity at soine point to subject the intrusion to the neutral and detached scrutiny of a judicial officer before the evidence obtained therefrom may be admitted in a criminal proceeding against the accused. ${ }^{122}$

Applying these criteria, the court refused to overturn a murder conviction based on evidence that included a photograph and handwriting exemplar obtained before arrest pursuant to Colorado's Rule 41.1. ${ }^{123}$ In arriving at this decision, the court clearly administered a Davis-like balancing formula to uphold the Rule.

Similarly, in State v. Grijalva, ${ }^{124}$ the Arizona Supreine Court upheld a statute that allows temporary pre-arrest detention to obtain evidence of identifying physical characteristics on less than probable cause. Pursuant to a pre-arrest detention order, the police obtained photographs of the defendant, his fingerprints, and six hairs from his head. ${ }^{125}$ When the defendant moved to suppress the evidence, the trial court denied the notion. On appeal, the court upheld the use of that evidence, as well as the constitutionality of the Arizona statute. The court declared that a "temporary detention order is not ... of the stature of a warrant necessitating probable cause. ... [A]n arrest is a uniquely harsh restriction of liberty with severe consequences for the one arrested; a detention for no more than three hours is a significantly lesser invasion." ${ }^{126}$ The court also emphasized that "the interest of society in the investigation of felonies is very high and the statute requires that it must be otherwise impossible to obtain the necessary identification evidence except in this inanner."127 According to the court, obtaining photographs or hair clippings involved a relatively small invasion of a person's privacy:

The degree of intrusion into the person's privacy is relatively slight. Photographs, more so than fingerprints, involve none of the probing

\footnotetext{
121. $638 \mathrm{P} .2 \mathrm{~d}$ at 32 .

122. Id. at 31-32.

123. Id. at 22-23.

124. 111 Ariz. 476, 533 P.2d 533, cert. denied, 423 U.S. 873 (1975).

125. Grijalva, 111 Ariz. at 477,533 P.2d at 534.

126. 111 Ariz. at 478,533 P.2d at 535 .

127. 111 Ariz. at 479,533 P.2d at 536 .
} 
that the Davis court found to mark a search of an unreasonable nature. Similarly, clipping several head hairs is only the slightest intrusion upon the body, if any at all, and does not constitute anytling unreasonable. ${ }^{128}$

Unlike Madson and Grijalva, however, the Nebraska Supreme Court in State v. Evans read the Nebraska scheme for identifying physical characteristics to require that police show both probable cause to believe that (1) a crime has been committed and (2) the person compelled to submit to nontestimonial identification procedures committed the crime. ${ }^{129}$ The statute itself did not specifically require the second part of the test; rather it required only the following:

(1) there is probable cause to believe that an offense has been committed; (2) that procurement of evidence of identifying pliysical claracteristics through nontestimonial identification procedures ... may contribute to the identification of the individual who committed sucl offense; and (3) that the identified or described individual has refused, or there is reason to believe lie will refuse, to voluntarily provide the desired evidence of identifying physical characteristics." 130

Relying on the legislature's decision not to specifically enact a "reasonable grounds to suspect" standard like that in Rule 41.1, the Nebraska court interpreted its statute to incorporate a traditional standard of probable cause.

No federal court has reviewed the constitutionality of any of the state statutes modeled after Rule 41.1, and no state court has ruled that its state statute is unconstitutional. Thus a number of states such as Colorado, Arizona, and Nebraska have gained experience in administering schemes for nontestimonial identification, as the Judicial Conference suggested. Their experience has shown that rules balancing government interests with individuals' fourth amendment privacy rights like Rule 41.1 work in fairly admimistering such procedures for nontestimonial identification.

\section{AdAPTiNg Rule 41.1 to DNA Typing}

Not only does Rule 41.1 work on its own terms incorporating numerous types of nontestimonial identification, but it also readily accommodates the use of DNA typing as an investigatory tool. Moreover, DNA typing is well suited to the balancing approach suggested by the Davis dictum and embodied in Proposed Rule 41.1. First, like finger-

128. Id.; see also Note, supra note 11 , at 518 (discussing Supreme Court's failure to take consistent position on whether Terry balancing test applies to all police intrusions that do not constitute full search and seizure or only if police practice is within the Terry exception).

129. 215 Neb. $433,442,338$ N.W.2d 788, 794 (1983).

130. Neb. Rev. Stat. § 29-3303 (1983). 
printing, DNA typing is an "inherently ... reliable and effective crime solving tool." 131 The state therefore has a strong interest in allowing its use on less than probable cause. The state interest in DNA typing may even be stronger than its interest in fingerprinting because police often discover forensic samples contaiming DNA at crime scenes where they are unable to recover clean fingerprints. ${ }^{132}$

Second, there is little possibility that law enforcement authorities will use DNA typing to harass individuals and thereby prejudice their privacy interests. If a suspect objects to blood testing, investigators can obtain DNA samples less imtrusively from skin or hair roots. In addition, officials only need to take a DNA sample once, and, because a suspect cannot alter his DNA structure, officials and the suspect can schedule testing at a convenient time after a magistrate reviews the application. Furthermore, authorities can take a sample for testing quickly, under medical supervision, and with mininal disruption of a suspect's daily life. Finally, because the typing process is still fairly expensive and labor intensive, ${ }^{133}$ officials have an incentive not to overuse it.

Third, Rule 41.1 even protects suspects' privacy concerus to a certain degree. DNA typing results in a bar code, which, according to experts, reveals very little beyond a suspect's identity. ${ }^{134}$ If a suspect's print does not match the forensic sample, under Rule 41.1, the suspect also can petition to have the sample and all related records destroyed. ${ }^{135}$ This protective measure prevents authorities from placing the DNA prints of exculpated suspects into a large computer database, as is done for fingerprinting, for use in later investigations or other more objectionable purposes. Furthermore, if the state destroys all records of an exculpated suspect's DNA test, no social stigma will follow that suspect; the public will never know that the authorities tested an exculpated suspect.

\section{Proposal For a DNA Typing Rule}

In order to balance government's interest in crime solution with individuals' fourth amendment rights, the states and the federal government should adopt a rule like Proposed Rule 41.1 that deals specifically with DNA typing. Lawniakers could even further tailor Rule 41.1 to satisfy the concerns of individual citizens about DNA typing.

131. Davis v. Mississippi, 394 U.S. 721, 727 (1969); see supra notes $45-48$ and accompanying text.

132. See LIFECODES CORP., supra note 32 , at 7-8.

133. White \& Greenwood, supra note 4, at 147.

134. See Burk, supra note 27, at 471.

135. Committee on Rules of Practice and Procedure, supra note 14, at 466. 
A better rule than Rule 41.1 would require law enforcement authorities to automatically destroy all tests and related records of nonmatching suspects' after the completion of the tests. ${ }^{136}$ The state thus would bear the burden of proof on the issue of destruction. In light of genetic privacy concerns, ${ }^{137}$ the state clearly lacks sufficient interest in retaining DNA prints of exculpated suspects. Furthermore, automatic destruction will satisfy critics' concerns by preventing the state from creating a DNA computer database containing confidential genetic information. ${ }^{138}$

The new rule regulating DNA typing also should expressly prohibit any form of interrogation during a suspect's brief detention for testing. ${ }^{139}$ The current rule only provides that "the person will be under no legal obligation to submit to any interrogation." 140 The rule should leave no temptation for the police to question or harass suspects and this formulation leaves room for abuse.

To further guard against personal harassment, the rule also should allow suspects to have counsel present during testing. ${ }^{141}$ While the testing procedure stops slrort of actual arrest, the suspect undergoing testing still should have access to legal assistance to inform them of their legal rights. This safeguard also will help ensure that authorities do not use the procedure for interrogation purposes or detain suspects for longer than necessary.

To help guard against social stigma associated witl the procedure, the rule sliould require authorities to perform all testing in a hospital or other medical facility, rather than at a police station. Such a requirement also ensures that authorities will perform testing under medical supervision and will use proper procedures. For the same reasons, the rule should permit suspects to appear at typing locations voluntarily, rather than by police escort. ${ }^{142}$

Finally, the new rule should expressly provide for an expedited appeal process, whereby suspects could preemptively challenge testing orders. ${ }^{143}$ Sucli a process would allow suspects to submit evidence to show that DNA typing would be unreasonable under their particular circumstances.

136. See Note, supra note 11 , at 741.

137. See supra note 63 and accompanying text.

138. See supra notes 75-78 and accompanying text.

139. See Note, supra note 6, at 738-39 (proposing that suspects receive Miranda warnings).

140. Committee on Rules of Practice and Procedure, supra note 14, at 465.

141. See Comment, supra note 87, at 154-56.

142. See id. at 140 n.47.

143. See Note, supra note 6 , at $734-36$. 


\section{CONCLUSION}

By enacting a rule for DNA typing modeled on Proposed Rule 41.1, the states and the federal government can balance the coinpeting interests implicated by this new crime-solving technique. Such a rule would authorize the state to use DNA typing in compelling situations, but also would protect suspects from unreasonable uses of the process. While authorities have yet to routinely use DNA typing in crine investigation, ${ }^{144}$ as the technology develops and authorities gain more experience with it, DNA typing is certain to become a major force in crime solution. The proposed rule, modeled on Rule 41.1, offers the best way to use this new investigatory tool because it neither prejudices individual rights nor shackles law enforcement officials.

Clare M. Tande

144. See Thompson, supra note 45 , at 42 (approximately six states' prosecutors have used genetic fingerprinting evidence at trial). 